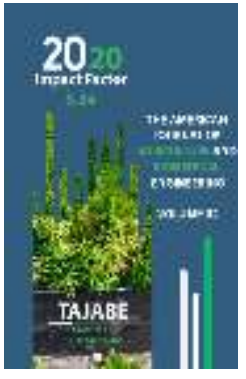

Journal Website: http://usajournalshub.c om/index,php/tajabe

Copyright: Original content from this work may be used under the terms of the creative commons attributes 4.0 licence.

\section{Efficiency Indicators Of Phosphorus In The Development And Cultivation Of Potato}

Sultonova N.

Gulistan State University, Uzbekistan

Qo'shiyev Kh.

Gulistan State University, Uzbekistan

\title{
ABSTRACT
}

In order to determine the effect of the phosphoric element on the growth and development of potatoes, their productivity and efficiency, studies were conducted to determine the optimal nutrient medium in laboratory and field conditions. In nutritional variants with a concentration of $P$ of $16 \mathrm{mg} / \mathrm{I}$ and $48 \mathrm{mg} / \mathrm{I}$, the $\mathrm{P}$ content is higher than in leaves. In nutritional variants with a concentration of $48 \mathrm{mg} / \mathrm{I}$, there is a smaller number of leaves compared to the $16 \mathrm{mg} / \mathrm{l}$ concentration variants and a delay in the flowering period. It was found that the nutrients contain important vital microelements in plant tissue and the output composition in variants of the concentration of $P$ is $16 \mathrm{mg} / \mathrm{l}$.

\section{KEYWORDS}

Potato, phosphorus, nutrition, optimal conditions, vegetation

\section{INTRODUCTION}

Meeting the growing food needs of the population is one of the most pressing issues. Almost 30\% of the daily diet of the population of many countries of the world is made up of potato products. The leader in potato cultivation is China (70 million tons), Russia (38.6 million tons), and India (23.9 million tons). tons), the United States (19.7 million 
tons), Ukraine (19.5 million tons), Germany (10 million dollars. tons) in the countries created many varieties of potatoes, and the average yield of potatoes in these States does not exceed 36.6-43.7 tons per hectare (http//xn.80.aplem.xn..plai/analytics/Mirovoj rynok kartofela/; https://royal-fresh.ru/mirovjryinok-kartofelya.2018.html).

Potato tuber is rich in carbohydrates, vitamins and antioxidants that are essential for the human body, and plays an important role in nutrition (Camire et al., 2009; brown, 2005). Therefore, in agriculture, special attention is paid to the development of potato production and obtaining a high-quality crop.

When determining the quality of mashed potatoes, an important role is played by the element phosphorus ( $P$ ). $P$ is one of the elements that is required in potatoes in large quantities compared to other crops. It consists of adenosine triphosphate (ATP), which plays a key role in plant metabolism and energy, as well as a component of nucleic acids, which are the most important vital biomolecules. It is also the most important component of phospholipids, which provide the formation of R-coenzyme and cell membranes (Ragotama 2000; Marshner 2012; Rosen et al. 2014).

Due to the fact that $R$ is poorly soluble in water, the plant will be more difficult to digest from the soil. This leads to a decrease in the yield and quality of potato tubers. In the case of insufficient $R$, the rate of root hair formation decreases, which leads to a decrease in the level of nutrient uptake from the soil (Hopkins 2013, Hopkins, etc.). 2014). For this reason, in order to provide the plant with sufficient $R$ and meet its needs, in most cases, there are cases of applying more phosphorus fertilizers to the soil than the norm (Hopkins et al., 2010). Taking into account the physical and chemical properties of the soil and the degree of assimilation of element $P$ in it, some researchers have proposed norms of phosphorus fertilizers (Mayer et al.) From 100 to $400 \mathrm{~kg}$ per hectare when growing potatoes. 2002; Hopkins and others. 2014).

According to some studies conducted in order to increase the rate of plant uptake from the soil by element $P$, it is recommended that the frequency of fertilization in the soil is adjusted for the influence of external factors (Hopkins 2013). Before using $P$ as a fertilizer, it is necessary to check the amount of soil using the Mehlich III method (Pote et al., 1996). Usually, the low Level of p-fertilizers and the need for it are determined by testing the level of $P$ in the soil. However, there are differences between different types of soil: in sandy soils, for example, in sandy soils, the $P$ level is lower, and in sandy soils, the P level is higher, which indicates high yield reactions (Rosen et al.). 2014). The concentration of phosphorus in soils is very low, in agricultural soils it ranges from about 0.002 to $2 \mathrm{mg} \mathrm{l-1}$ (Fardeau, 1996).

In addition, a lack of $\mathrm{P}$ may further reduce root growth due to its role in cell division (Rosen et al.). 2014). Accordingly, as a result of insufficient work of the root system, the development of vegetative organs of the plant slows down.

One of the biological features of potatoes is due to the fact that the growth of tusks and tubers does not occur simultaneously. First of all, seedlings develop during the flowering period and form terrestrial biomass,

In the early stages of potato development, potatoes do not require special mineral nutrition, since the necessary supply of substances is contained in the nodes. And at later stages of development, the need for 
mineral nutrition increases. In accordance with this study, a study was conducted to determine the state of potato demand for $p$ at the stage of vegetative development and changes occurring during the maturation of the P-element.

\section{MATERIALS AND METHODS}

The potato plant is extremely demanding of the main nutritional elements. From nitrogen fertilizers on unsalted lands, it is recommended to apply ammonium sulfate, and from potash fertilizers-potassium sulfate fertilizers. If the earth is salty, it is desirable to give nitrogen fertilizer in the form of ammonium nitrate. A good result is that when watering, the juice method is used instead of potassium.

The study was conducted in the greenhouse of the laboratory " Experimental biology "of Gulistan state University under the influence of various concentrated nutrient solutions of potatoes of the"Pskom" variety.

For the study, nutrient solutions of phosphorus were selected in three different concentrations (4, 16, $48 \mathrm{mg} / \mathrm{l})$ and experiments were conducted in four reactions. In the studied conditions, the air temperature averaged 22-240C. Natural light was 12 hours. In order to study the effect of macronutrients on the physiological properties of potatoes, as well as to conduct physiological and biochemical analysis, the "Pscom" variety, created by researchers of the "research Institute of potato production of the Republic of Uzbekistan", was selected for research. The seed nodes selected for the study were placed in 16-liter plastic bottles with sand. Based on the following table, a Hoagland solution was prepared (Hoagland \& Arnon, 1950) and applied three weeks after planting (table 1). 
The American Journal of Agriculture And Boimedical Engineering (ISSN - 2689-1018)

Published: August 11, 2020 | Pages: 44-51

Doi: https://doi.org/10.37547/tajabe/Volume02Issue08-04

Table 1

Results of application of the Hoagland solution at the stages of growth and development of potatoes in sand plastic bottles

\begin{tabular}{|c|c|c|c|c|}
\hline No & Components & mg per 1 liter & mg per 10 liter & mg per 100 liter \\
\hline $\mathbf{1}$ & $\mathrm{NH}_{4} \mathrm{NO}_{3}$ & 480 & 4800 & 48000 \\
\hline $\mathbf{2}$ & $\mathrm{KNO}_{3}$ & 303 & 3030 & 30300 \\
\hline $\mathbf{3}$ & $\mathrm{KCl}$ & 223,5 & 2235 & 22350 \\
\hline $\mathbf{4}$ & $\mathrm{CaNO}_{3}$ & 2776 & 27760 & 277600 \\
\hline $\mathbf{5}$ & $\mathrm{MgSO}_{4}{ }^{*} 7 \mathrm{H}_{2} \mathrm{O}$ & 1355 & 13550 & 135500 \\
\hline $\mathbf{6}$ & $\mathrm{H}_{3} \mathrm{BO}_{3}$ & 182 & 1820 & 18200 \\
\hline $\mathbf{7}$ & $\mathrm{CuSO}_{4}{ }^{*} \mathrm{H}_{2} \mathrm{O}$ & 0,2 & 2 & 20 \\
\hline $\mathbf{8}$ & $\mathrm{FeCl}_{3}$ & 24 & 240 & 2400 \\
\hline $\mathbf{9}$ & $\mathrm{MnCl}_{2}{ }^{*} \mathrm{H}_{2} \mathrm{O}$ & 3,5 & 35 & 350 \\
\hline $\mathbf{1 0}$ & $\left(\mathrm{NH}_{4}\right)_{6} \mathrm{Mo}_{7} \mathrm{O}_{24}{ }_{4} \mathrm{H}_{2} \mathrm{O}$ & 1,37 & 13,7 & 137 \\
\hline $\mathbf{1 1}$ & $\mathrm{ZnCl}_{2}{ }_{2} \mathrm{H}_{2} \mathrm{O}$ & 0,23 & 2,3 & 23 \\
\hline $\mathbf{1 2}$ & $\mathrm{KH}_{2} \mathrm{PO}_{4}$ & $0,4,16,48$ & & \\
\hline
\end{tabular}

Four weeks after planting, the plant was moved to five-liter plastic pots. The soil laid on canvas was brought from Uzbekistan in the Syrdarya region using LCK 339 (LASA AGRO) test cuvettes in a spetphotometer with the SMART Fertility program in the laboratory "Experimental biology" (table 2)

Table 2

Results of determining the elemental composition of soil in a spetrophotometer using the software SMART Fertility

\begin{tabular}{|c|c|c|c|c|c|c|c|c|c|c|c|c|c|c|}
\hline № & 1 & 2 & 3 & 4 & 5 & 6 & 7 & 8 & 9 & 10 & 11 & 12 & 13 & 14 \\
\hline $\begin{array}{c}\text { Orga } \\
\text { nic } \\
\text { conte } \\
\text { nt }\end{array}$ & $\begin{array}{c}\mathrm{NO}_{3}^{-}-\mathrm{N}^{-} \\
\mathrm{mg} / 10 \\
\text { Og }\end{array}$ & $\begin{array}{c}\mathrm{P}_{2} \mathrm{O} \\
5 \\
\mathrm{mg} / 10 \\
\mathrm{og} \\
\end{array}$ & $\begin{array}{c}\mathrm{K}_{2} \mathrm{O} \\
\mathrm{mg} / 1 \\
00 \mathrm{~g}\end{array}$ & $\begin{array}{c}\mathrm{NH}_{4}{ }^{+} \\
-\mathrm{N} \\
\mathrm{mg} / 1 \\
\mathrm{oog}\end{array}$ & $\begin{array}{c}\mathrm{SO}_{4} \\
2 \\
\mathrm{mg} / 10 \\
\mathrm{og} \\
\end{array}$ & $\begin{array}{c}\text { Mg }^{2} \\
+ \\
\mathrm{mg} / 10 \\
\text { og }\end{array}$ & $\begin{array}{c}\mathrm{Fe} \\
\mathrm{mg} \\
/ \mathrm{I}\end{array}$ & $\begin{array}{c}\mathrm{Mo}^{6} \\
+ \\
\mathrm{mg} / 10 \\
\mathrm{og} \\
\end{array}$ & $\begin{array}{c}\mathrm{Zn} \\
\mathrm{mg} / \\
100 \\
\mathrm{~g}\end{array}$ & $\begin{array}{c}\mathrm{Mn} \\
\mathrm{mg} / 1 \\
00 \mathrm{~g}\end{array}$ & $\begin{array}{c}\mathrm{Cl}^{-} \\
\mathrm{mr} / \\
\pi\end{array}$ & $\begin{array}{c}\mathrm{Cu} \\
\mathrm{mg} / \\
100 \\
\mathrm{~g}\end{array}$ & $\begin{array}{c}\text { В } \\
\text { мг/ } \\
\pi\end{array}$ & $\begin{array}{l}\mathbf{P} \\
\mathrm{H}\end{array}$ \\
\hline $\begin{array}{c}\text { per } \\
100 g \\
\text { ofsub } \\
\text { stanc } \\
\text { e }\end{array}$ & 1,60 & 30,1 & 21,1 & 0,601 & $\begin{array}{c}60 \\
4\end{array}$ & 204 & 10,3 & 11,5 & $\begin{array}{c}0,43 \\
2\end{array}$ & $\begin{array}{c}0,19 \\
3\end{array}$ & $\begin{array}{l}15 \\
0\end{array}$ & $\begin{array}{l}0,8 \\
98\end{array}$ & $\begin{array}{l}0,2 \\
66\end{array}$ & $\begin{array}{l}8, \\
37\end{array}$ \\
\hline
\end{tabular}


Based on the detected content, in order to optimize the soil composition, an additional amount of mineral feed was calculated using the software SMART Fertilityto determine and

\section{Table 3}

\section{Optimal indicators developed for the supply of nutrients to the soil using the software SMART Fertility}

\begin{tabular}{|l|l|l|l|}
\hline № & \multicolumn{1}{|c|}{ Nutrients } & \multicolumn{1}{c|}{ Amount } & Weight \\
\hline 1 & $\mathrm{Zn}-\mathrm{EDTA} 13 \%$ & 0,17 & $\mathrm{~kg}$ \\
\hline 2 & $\mathrm{NH}_{3} \mathrm{SO}_{4}$ & 293.86 & $\mathrm{~kg}$ \\
\hline 3 & $\mathrm{KNO}_{3}$ & 49,36 & $\mathrm{~kg}$ \\
\hline 4 & $\mathrm{KH}_{2} \mathrm{PO}_{4}$ & 30 & $\mathrm{~kg}$ \\
\hline 5 & $\mathrm{~B}$ & 0,54 & $\mathrm{~kg}$ \\
\hline 6 & $\mathrm{Cu}-\mathrm{EDTA} \mathrm{14 \%}$ & 0,04 & $\mathrm{~kg}$ \\
\hline 7 & $\mathrm{Mn}-\mathrm{EDTA}$ & 8,61 & $\mathrm{~kg}$ \\
\hline 8 & $\mathrm{CaCl}$ & 29 & $\mathrm{~kg}$ \\
\hline
\end{tabular}

The soil of $4 \mathrm{~kg}$ was placed on plastic pots, and two weeks after planting the plants, except for the control variant, were fed with optimal nutrients and fed with concentrated nutrient solutions of phosphorus (4, 16, $48 \mathrm{mg} / \mathrm{l}$ ). $\mathrm{H}_{2} \mathrm{PO} 4$ was used as a phosphorous fertilizer.

Phenological indicators of plants after 4 weeks of sowing V. A. based on Batmanov's method, macronutrients were identified and analyzed in the composition using the LCK 339 (LASA AGRO)test method, $50 \mathrm{mg}$ of leaf samples were obtained from each variant.

\section{OBTAINED RESULTS AND THEIR ANALYSIS}

With a good crop of potatoes, it is very important to maintain a balance based on the provision of nutrients. (Yara, 2017). In addition to organic fertilizers, mineral fertilizers play an important role in obtaining higher and more prepare the optimal feed for growing potatoes in the soil(table 3 ).

29

stable potato yields. To get the maximum effect based on the use of mineral fertilizers, it is advisable to take into account their soil conditions and condition, depending on the characteristics of the cultivated varieties. It is important to take into account the composition and structure of the soil, the $\mathrm{pH}$ indicator, the content of humus, phosphorus, potassium, the type and amount of organic fertilizers, as well as the type of crop previously planted on the land area. This allows you to specify the composition and amount of fertilizers when growing potatoes. But it should also be noted that fertilizers of potato varieties can also be diverse. Insufficient or increased content of any mineral elements negatively affects the growth and yield of potatoes. We can see this from the following results (table 4).

Table 4

Results of phenological observations of potato growth and development under the influence of $\mathrm{KH}_{2} \mathrm{PO}_{4}$ with various concentrations 
The American Journal of Agriculture And Boimedical Engineering (ISSN - 2689-1018)

Published: August 11, 2020 | Pages: 44-51

Doi: https://doi.org/10.37547/tajabe/Volume02Issue08-04

2020: $5 \cdot 34$

\begin{tabular}{|c|c|c|c|c|}
\hline № & $\begin{array}{c}\mathbf{K H}_{2} \mathbf{P O}_{4} \text { with influence } \\
\text { to Umid-2 variety }\end{array}$ & $\begin{array}{c}\text { Number of } \\
\text { leaves } \\
\text { (+20 days) }\end{array}$ & $\begin{array}{c}\text { Height of plants } \\
(\mathbf{s m})\end{array}$ & $\begin{array}{c}\text { The period from } \\
\text { budding to } \\
\text { flowering (days) }\end{array}$ \\
\hline 1 & Control & 9 & 14 & 34 \\
\hline 2 & $4 \mathrm{mg}$ & 11 & 19 & 32 \\
\hline 3 & $16 \mathrm{mg}$ & 16 & 24 & 28 \\
\hline 4 & $48 \mathrm{mg}$ & 12 & 24 & 29 \\
\hline
\end{tabular}

The table shows that in the $2 \mathrm{mg} / \mathrm{l}$ and $4 \mathrm{mg} / \mathrm{l}$ concentration variants, compared to the control and concentratedKH2PO4solutions of $48 \mathrm{mg} / \mathrm{l}$, a high P content was observed in the leaves. However, despite the high content indicators, it can be noticed that in variants with a concentration of $48 \mathrm{mg} / \mathrm{l}$, the number of leaves is less than in variants with a concentration of $16 \mathrm{mg} / \mathrm{l}$, and the flowering period begins later (Fig.1).

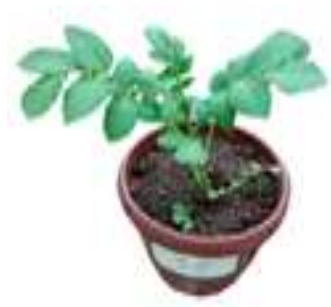

1) намерат

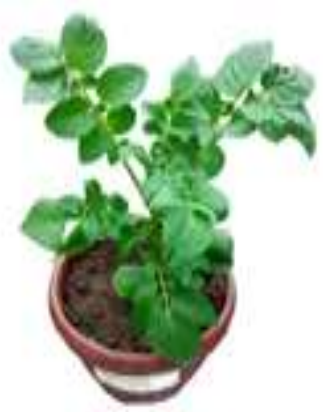

2) $\mathrm{KH} 2 \mathrm{PO4}, 4 \mathrm{MI}$

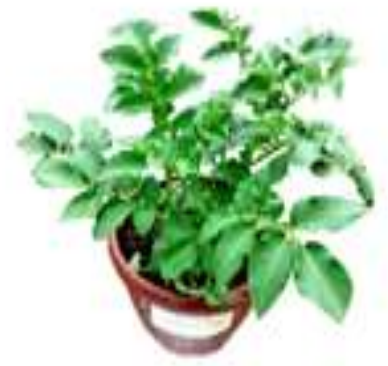

3) КН2 $\mathrm{PO4}, 16 \mathrm{MI}$

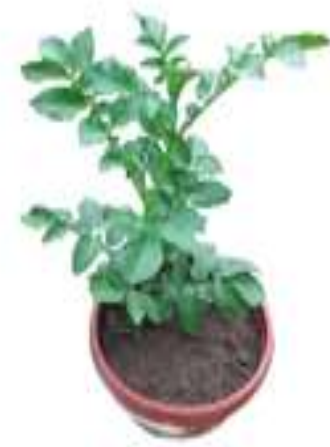

4) $\mathrm{KH} 2 \mathrm{PO4}, 48 \mathrm{MI}$

\section{Figure 1. Indicators of vegetative organs of potatoes in a nutrient medium with different amounts of phosphorus.}

From the results obtained, it can be seen that the increase in the content of phosphorus in the nutrient complex is due to an increase in the above-ground mass and the number of vegetative organs, including leaf.The optimal indicator is the $\mathrm{pH}$ content in nutrients of 16 $\mathrm{mg} / \mathrm{l}$. It turned out that the increased content of phosphorus in the nutrient complex leads to a decrease in the mass and number of vegetative organs. This can lead to a lower yield.

The content of various amounts of phosphorus in nutrients also affects the amount of macro-and microelements in the tissues of vegetative organs (table 5). 


\section{Table 5}

\section{The number of macronutrients accumulated in potato leaves under the influence of $\mathrm{KH}_{2} \mathrm{PO}_{4}$ with various concentrations}

\begin{tabular}{|c|c|c|c|c|c|c|}
\hline № & $\begin{array}{c}\text { Pskom } \\
\text { variety }\left(\mathrm{KH}_{2} \mathrm{PO}_{4}\right)\end{array}$ & $\mathbf{P}_{\mathbf{2}} \mathbf{O}_{5} \mathbf{m g} / \mathbf{1 0 0 g}$ & $\begin{array}{c}\mathbf{K}_{\mathbf{2}} \mathbf{O} \\
\mathbf{m g} / \mathbf{1 0 0 g}\end{array}$ & $\begin{array}{c}\mathbf{M g}^{\mathbf{2 +}} \\
\mathbf{m g} / \mathbf{1 0 0 g}\end{array}$ & $\begin{array}{c}\mathbf{M n} \\
\mathbf{m g} / \mathbf{1 0 0 g}\end{array}$ & $\mathbf{p H}$ \\
\hline 1 & Control & 21,1 & 0,257 & 0,672 & 0,101 & 7,41 \\
\hline 2 & $4 \mathrm{mg}$ & 22,9 & 0,268 & 0,672 & 0,187 & 6,94 \\
\hline 3 & $16 \mathrm{mg}$ & 24,1 & 0,297 & 0,867 & 0,159 & 6,72 \\
\hline 4 & $48 \mathrm{mg}$ & 25,3 & 0,301 & 0,822 & 0,136 & 5,86 \\
\hline
\end{tabular}

The $\mathrm{pH}$ level of the soil can have a decisive influence on the solubility ofP fertilizers. The neutral $\mathrm{pH}$ is in the best range from 6.0 to 7.5 in terms of solubility $\mathrm{P}$ However, the acid-base environment can also negatively affect the presence of pH (Hopkins 2013; Rosen et al. 2014). In acidic soil conditions, $P$ forms a highly soluble mineral precipitate with aluminum, iron, or manganese, while in alkaline soils a similar reaction occurs with magnesium or calcium (Hopkins 2013).

Barben and others (2010a) noted that an increase in $R$ in the nutrient solution dramatically increased the concentration of $\mathrm{Mn}$ in the roots alone. Further research has shown that increasing the concentration of $P$ in the tubers and stems of the potato plant significantly increases the amount of MN. It should be noted that $R$ does have a positive effect on the uptake and movement of $\mathrm{Mn}$ (Barben et al.,2010).

As a result of the study ( $48 \mathrm{mg} \mathrm{L-1)}$ ), there was a decrease in the concentration of $\mathrm{Mn}$ due to the fact that in the feed version, the concentrated nutrient solutions were acidic $\mathrm{pH}$ (5.86).

At a low $R$ concentration, the concentration of magnesium (mg) in the root and femoral biomass is identical to the concentration of magnesium. When the concentration of phosphorus in a solution of $16 \mathrm{mg} / \mathrm{l}$, an increase in the concentration of $\mathrm{mg}$ in the roots at concentration of phosphorus in solution is $2 \mathrm{mg} / \mathrm{l}$ was observed a decrease in the concentration of $\mathrm{mg}$ in the POI. The increase in $\mathrm{Mg}$ concentration at the root may be related to the demand for $\mathrm{Mg}$ in energy transfer reactions in cells (Marshner, 1995). It is also an activator of the Mg kinase enzyme and regulates many reactions, including an important role in phosphate transport (Fageria, 2001). Accordingly, the analysis of the mineral composition of potato leaves showed that when the concentration of $P$ increases, the concentration of $\mathrm{mg}$ also increases.

In the enzyme function of potato crops, an important role is played by stimulating the synthesis of starch C (Hawker et al.). 1979). For the production of high biomass and the development of leaf area, it is necessary to provide a sufficient amount of element $\mathrm{C}$. If there is a lack of $C$, there may be a decrease in the number of leaves, as well as a decrease in the size of the leaves. This can be linked to the role of $\mathrm{C}$ in osmoregulation and cellular 
expansion (Gerardo et al. 2010; Jaklin et al. 2016).

\section{CONCLUSION}

1. The results of phenological observations over growth and development of potatoes under the influence of different concentrations of $\mathrm{KH}_{2} \mathrm{PO}_{4}$ increasing number of leaves in variants of the phosphorus concentration of $16 \mathrm{mg} / \mathrm{l}$, and the length of the flowering period corresponds to the period of vegetative development.

2. To positively implement the interaction of micro - and macronutrients, which play an important role in the growth and development of potatoes, it is desirable to maintain the $\mathrm{pH}$ of the soil from 6.0 to 7.5 .

3. In nutritional variants with a concentration of $16 \mathrm{mg} / \mathrm{l}$ And $48 \mathrm{mg} / \mathrm{l}$, the $\mathrm{pH}$ content in the leaves is higher. But, despite the high content indicators, in the nutritional variants with a concentration of $48 \mathrm{mg} / \mathrm{l}$, there is a smaller number of leaves compared to the variants with a concentration of 16 $\mathrm{mg} / \mathrm{l}$, and the flowering period is delayed.

\section{REFERENCES}

1. Hoagland, D.R., Arnon, D.L., 1950. The Water Culture Methods for Growing Plants Without Soil. California Agriculture Experiment Station, Berkeley (Bulletin, 347).

2. Alsmeek. P.I. Physiology of potatoes / P.I. Alsmeick, A.M. Ambrosov, A.C. Evening and others // Ed. B.A. Ruby. M .: Kolos, $1997 .--272$ p.
3. Bardyshev, M.A. Mineral nutrition of potatoes / M. A. Bardyshev; scientific ed. N. A. Dorozhkin, Minsk: Science and Technology. - 1984. - 191 p.

4. Mirjam Koch, Marcel Naumann, Elke Pawelzik, Andreas Gransee, Heike Thiel. 2019. "The Importance of Nutrient Management for Potato Production Part I: Plant Nutrition and Yield" 104-112

5. Fageria VD (2001) Nutrient interactions in crop plants. J Plant Nutr 24: 1269-1290. https://doi.org/10.1081/PLN-100106981

6. Hawker JS, Marschner H, Krauss A (1979) Starch synthesis in developing potato tubers. Physiol Plant 46: 25-30. https://doi.org/10.1111/j.13993054.1979.tbo3180.x

7. Hopkins BG, Ellsworth JW, Bowen TR, Cook AG, Stephens SC, Jolley VD, Shiffler AK, Eggett D (2010) Phosphorus fertilizer timing for Russet Burbank potato grown in calcareous soil. J Plant Nutr 33: 529540.

https://doi.org/10.1080/019041609035062 66

8. Hopkins BG, Horneck DA, MacGuidwin AE (2014) Improving phosphorus use efficiency through potato rhizosphere modification and extension. Am J Potato Res 91: 161-174. https://doi.org/10.1007/s12230-014-9370-3

9. Batmanov V. A. Notes on the theory of phenological observations // Nature rhythms of Siberia and the Far East, part 1. Irkutsk: Siberian Book Publishing House. 1967. S. 7-30.

10. Beideman I. N. Methods of studying the phenology of plants and plant communities. Novosibirsk: Nauka, 1974. 154 S. 